\title{
Legal Integration in the European Union and the Eurasian Economic Union: Comparative Analysis ${ }^{1}$
}

\author{
O. Pimenova
}

Oxana Pimenova - PhD, Head of Section for liaison with federal government authorities, Permanent Staff of the Council of Federation of the Federal Assembly of the Russian Federation; 26 Bolshaya Dmitrovka Str., Moscow, 103426, Russian Federation; E-mail: oxana_krasnova@mail.ru

\begin{abstract}
The author studies the communitarian and conventional models of legal integration used in the European Union (EU) and the Eurasian Economic Union (EAEU), respectively. The purpose of this comparative legal analysis is to determine unique features reflecting differences between these models. Particular focus is on the examination of legal acts of public bodies of the EU and the EAEU - their legal nature, place, role and the characteristics of their implementation in the national legal systems of their members. The author also analyses how the Court of the European Union and the Court of the Eurasian Economic Union control the enforcement of legislation of the EU and the EAEU, primarily in those cases where the courts assess justifications provided by supranational public bodies of these unions when they pass legal acts creating rights and obligations directly for citizens of the EU and economic entities of the EAEU. The article offers a rationale for the concept stating that the absolute priority of integration law over national legislation and the binding power of decisions of a supranational court for all participants of integration relations are the key milestones of supranational legal integration; when these milestones are achieved, it is possible to open borders not only for economic cooperation, but also for other forms of collaboration not linked tightly to the general processes of transnationalization of the economies.
\end{abstract}

Key words: European Union; Eurasian Economic Union; supranational status; legal integration; legislative act; judicial control; national parliaments; democratic legitimacy; inter-institutional consensus

For citation: Pimenova O. (2019) Legal Integration in the European Union and the Eurasian Economic Union: Comparative Analysis. International Organisations Research Journal, vol. 14, no 1, pp. 76-93 (in English). DOI: 10.17323/1996-7845-2019-01-05

${ }^{1}$ The editorial board received the article in April 2018. 
The lack of effective integration law makes

it impossible to accomplish the goals and tasks of integration.

Lev Entin [2009, p. 238]

\section{Introduction}

In view of the "multi-level, multi-stage and non-linear design of international integration processes" [Kashirkina, Morozov, 2012, p. 17], all integration associations endeavor to attain their objectives by searching for and utilizing regulatory methods and tools that ensure the most appropriate balance between the interests of an association and those of its members. Such balance allows an association to better achieve the intended aims [Lenaerts, Nuffel, 2011, p. 134] without developing biases or giving preference to decisions at a "better" level of government and without the excessive overlapping intervention of public bodies in each other's competences.

The law of integration associations is special. Created in all cases on the basis of international treaties, integration law retains some elements of international law [Iumashev, 2006, p. 75], but it also penetrates the national legislative frameworks of members by substantially modifying these frameworks and creating within them unified or harmonized regulatory tools to foster integration. In the process of development, integration law acquires specific features depending upon the goals of an integration association and the willingness of members to share their sovereignty. This may occur not only by handing over (delegating) certain authorities and elaborating practices of coordinated interaction with supranational institutions, but also by using national regulatory tools to secure the implementation of legislative acts of associations, their institutions and governing bodies in states and in relation to their citizens. To analyze these features, this paper studies two integration associations, the European Union (EU) and the Eurasian Economic Union (EAEU), which have chosen different pathways of integration - a communitarian one and conventional (traditional) one. The study is preceded by the short overview of these pathways.

\section{Theoretical Background}

It would be fair to say that scholars studying European integration do not pay much attention to analyzing methods of integration development. Most experts of European integration are more interested in evolution and justification of the supranational nature of the EU and its legal, economic and institutional aspects [Majone, 2009, p. 2] rather than in examining the tools and means of attainment of supranational objectives. It feels like this preferential focus on supranational aspects of European integration may be explained by a fear of undermining the consistent trend within the last 30 years 
(since the adoption of the Single European Act, ${ }^{2}$ which paved the way and formed the legislative basis for the comprehensive application of a communitarian method of legal integration in relation to almost all issues of integration development ${ }^{3}$ ) to strengthen normative integration. Even the concepts of supranationalism and intergovernmentalism as key theoretical blocks of European integration policy have been infused with a strictly contextual meaning.

Usually, researchers in European integration matters consider supranationalism as an extension of integration development, while intergovernmentalism has become a somewhat negative notion as it appears to be closely related to regionalism and even separatism, and thus not beneficial in the context of supranational integration [Middelaar, 2013, p. 5]. Leaving aside the semantic details of supranationalism and intergovernmentalism as ideas that have been already widely studied not only in the international but also in Russian literature [Varlamova, 2014; Meshcheriakova, 2014; Chirkin, 2016], it would be true to say that, being the essential concepts of communitarian and conventional methods of integration, supranationalism and intergovernmentalism contribute to the achievement of integration development using their own, more relevant, tools.

For the communitarian method, such tools are legislation applied directly and on a priority basis as well as legal principles determining the application of such legislation while still configuring it. ${ }^{4}$ This method is also called the "community method." According to the position outlined in the official document of the EU Commission, it involves the following key elements: the right of legislative initiative of the EU Commission; the responsibility of the EU Council and European Parliament to pass budgetary and legislative acts; participation of the EU Commission along with national parliaments in the execution of a single implementation policy in the EU territory; and a special role of the Court of Justice of the European Union (CJEU) in protecting and advancing EU legislation [EU Commission, 2001, p. 8]. As long as the communitarian method requires members to delegate some of their authorities to the integration association, supranational institutions here play a key role as the actors that adopt supranational acts and engage as facilitators between states in their relationships with each other and with the EU over disputes emerging in relation to the delegation of authorities, while integration itself is positioned as "[national] sovereignty tamed" [Magnette, 2000, p. 117]. The conventional method, on the contrary, recognizes that states, or more exactly, their governments as key players in making integration decisions, are superior in the development and pursuit of integration aims [Puetter, 2014, pp. 854-70]. According to this method, supranational decisions result from the interaction of national govern-

${ }^{2}$ The Single European Act has not only provided the EU Commission with a range of important functions in regulating the single domestic market and its social and environmental facets, but also improved the judiciary system by creating a court of first instance. These innovations have become major landmarks in the normative integration of the EU.

${ }^{3}$ Excluding such sensitive areas, which later were given special regulatory status, as foreign policy and security policy, equity, justice, cooperation of the police and the judiciary.

${ }^{4}$ This is a specific characteristic of the evolvement of EU law where two streams of the European legal tradition meet - Romano-Germanic law and common law [Moorhead, 2012, pp. 126-43]. 
ments and their coordinated efforts, and so this method is also theoretically called the method of intergovernmental integration [Uçarer, 2013, p. 293].

While theoretically different, in practice the communitarian and conventional methods of integration have many tangency points. When one method is used some aspects of the other are also applied. It is important to note that since both methods have the common subject of regulation (integration and integration relations), it does not make practical sense to force an exclusiveness of application of any of these methods taken separately. Thus, communitarian integration that mostly takes place in the EU abounds with examples of when intergovernmental tools are used to ensure a better attainment of objectives of regulatory development. One can talk here not only about an active lawmaking role for the intergovernmental EU Council, which is a co-legislator in the EU along with the European Parliament, but also about countless so-called de novo bodies of collective decision-making ${ }^{5}$ created at the level of ministers and public servants representing national governments and positioned to deal with a number of crucial complex technical issues. In this regard, the purpose of this article is not to counter one integration model with the other, but to reveal elements that may be useful for ensuring a better achievement of core aims pursued in the process of integration.

\section{Legal Integration in the European Union}

The EU follows the communitarian model of integration, which was conceptually described in the Van Gend et Loos v. Administratie der Belastingen case as follows: "The European Economic Community constitutes a new legal order of international law for the benefit of which the states have limited their sovereign rights, albeit within limited fields, and the subjects of which comprise not only the Member States but also their nationals." In another case, Flaminio Costa v. E.N.E.L., the CJEU stated that "by contrast with ordinary international treaties, the EEC Treaty [Treaty establishing the European Economic Community] has created its own legal system which, on the entry into force of the treaty, became an integral part of the legal systems of the member states and which their courts are bound to apply." 7

Regarding the existing legal system in the EU, EU law enjoys supremacy (primacy) over the laws of its members. The adherence to this principle was first formulated in 1964 by the CJEU in the above-mentioned Flaminio Costa v. E.N.E.L. case, and was later confirmed in Declaration 17 of the Lisbon Treaty. In the EU, "a national constitution matters for implementing union law only to the extent it does not hamper the effective execution of union law" [Khol'tsinger, 2014, p. 40]. This means that, in order to regulate integration relations involving citizens, the EU uses as a matter of priority not national legislation, including constitutional acts, and not even international treaties

\footnotetext{
${ }^{5}$ Eurojust, Frontex, European Union Agency for Fundamental Rights, etc.

${ }^{6}$ Case C-26/62, Van Gend et Loos v. Administratie der Belastingen. Available at: https://curia.europa.eu/ jcms/jcms/j_6/en/ (accessed 12 September 2016).

${ }^{7}$ Case C-6/64, FlaminioCostav. E.N.E.L. Available at: https://curia.europa.eu/jcms/jcms/j_6/en/ (accessed 12 September 2016).
} 
entered into by national governments and ratified by national parliaments, but rather acts passed by the European Parliament and/or the EU Council that are supposed to be applied in full by individuals in the meaning set forth by the CJEU.

\section{Legislative Tools of Legal Integration in the EU}

The EU adheres to the intra vires rule, i.e. it acts only within the jurisdiction outlined in the founding treaties to pursue aims defined in these treaties. If a competence is not directly transferred to the EU by the treaties, it belongs to the members. This approach reflects the practice of vesting the EU with competences that was established in 1950s and still exists: members delegate authority in certain policy areas not entirely, but only in relation to some aspects that are clearly described in special enabling articles of the founding treaties - the so-called "legal bases." 8

To exercise its regulating competences the EU uses legislative acts. According to Article 289 of the Consolidated version of the Treaty on the Functioning of the European Union (TFEU) [EU, 2012], a regulating act adopted by the EU becomes an EU legislative act if it meets three conditions simultaneously: it is passed in the form of a regulation, directive or decision; it is adopted by the European Parliament and/or the EU Council; and it is adopted through the legislative procedure.

In 1992, at the Edinburgh summit, the European Council stated that "the form of action should be as simple as possible consistent with satisfactory achievement of the objective...The Community should legislate only to the extent necessary. Other things being equal, directives should be preferred to regulations" [cited in Lenaerts, 1993, p. 885]. This approach has changed the legislative culture of the EU. With the introduction of the Treaty of Maastricht, the EU "legislated less often (subsidiarity per se) and in a less intrusive manner" [Cooper, 2017, p. 36], mainly using directives as a form of regulation.

According to Article 288 of the TFEU [EU, 2012] a directive is a legislative instrument that makes it possible to avoid excessive regulation of relations at the EU level and leaves to the national authorities the choice of form and methods used to achieve their aims. But the problem is that every member of the EU, being an addressee of a directive, incorporates its provisions into domestic national legislation with a different degree of loyalty. As a result, implementation gaps occur from time to time in EU states, and some states bear much more of the expense associated with the implementation of a directive (legal, political, economic, social and environmental) as compared to other states. This factor complicates legal integration in the EU based on the principle of regulation via directives. To mitigate this negative effect, the CJEU has taken the approach described below.

${ }^{8}$ The "legal bases" identify specific issues, aims, procedures, institutions and types of acts that the EU should use to regulate certain issues within its jurisdiction. References to them are mandatory in a recital of each legislative act of the EU, and if it is not there or not included in full it leads to the cancellation the act by the CJEU. 


\section{Implementation of Legislative Acts in the EU}

Implementation of EU legislation is decentralized and based on the idea that interested individuals have a serious intention to exert control over the observance of EU legislation regulating their rights and freedoms. "The vigilance of individuals concerned to protect their rights amounts to an effective supervision in addition to... the diligence of the Commission [EU]." ${ }^{9}$ Civil actions by individuals play a greater role in legal integration of the EU as an instrument of pressure on national authorities for responsible and timely implementation of EU directives, as an alternative to the centralized supervision by the EU Commission.

N. V. Varlamova [2014, p. 13] argues that the EU has no "regional' and 'local' public agencies enforcing implementation of [EU] decisions." This is done by national authorities as they act as main implementors of EU law, and they are presumably liable for the damage affecting rights of individuals, including damage due to non-implementation or improper implementation of EU directives.

Starting with its first decision made in 1963 in the Van Gend en Loos v. Nederlandse Administratie der Belastingen ${ }^{10}$ case, the CJEU has stressed that protection of rights of individuals has been conducted by the Court in addition to protection provided by the Commission and the members. The CJEU reinforced this position later, in 1991, in the Francovich v. Italy ${ }^{11}$ case, where it confirmed a duty of members to consider actions filed against them by individuals for damages affecting rights of individuals incurred due to non-discharge or improper discharge of an obligation to implement EU directives. Finally, with the introduction of the Lisbon Treaty, the CJEU has been authorized to impose fines and penalties on EU members not only for non-implementation of its decisions, but also if a state has not reported to the EU Commission on measures taken to implement a EU directive within a certain time limit (Article 260, Para 3 of the TFEU) [EU, 2012].

This feature of legal integration in the EU - the use of instruments and means of national states - secures the efficiency of EU law in the framework of national legal systems, where national public institutions, according to G. Ellinek [2004, p. 413], having the "dominant nature," are endowed with a constitutional power based on the will of the voters to use tools forcing their citizens to comply with legal requirements of the EU. After all, it also explains why institutions implementing regulating competences of the EU try to have the process of adoption of EU legislative acts, as far as possible, brought into maximum proximity with citizens and take into account local, regional and national characteristics of relations that these acts regulate through institutionalization of involvement into the EU legislative process of bodies - national

${ }^{9}$ Case C-26/62, Van Gend et Loos v. Administratie der Belastingen. Available at: https://curia.europa.eu/ jcms/jcms/j_6/en/ (accessed 12 September 2016).

10 Ibid.

${ }^{11}$ Cases C-6/90 and C-9/90, Francovich v. Italy. Available at: https://curia.europa.eu/jcms/jcms/j_6/en/ (accessed 12 January 2017). 
parliaments - that are directly formed by citizens of states and that are politically accountable to their citizens.

\section{Judicial Review of Adoption of EU Legislative Acts}

The role of the CJEU in validating and developing supranational legal regulation cannot be overstated. Not envisaged in the founding treaties of the EU, the doctrine of direct effect of EU law and the doctrine of supremacy of EU law are "products of judge-made law" [Waele, Vleuten, 2013, p. 645] by their origin and nature. It is true to say that legal evolution of the EU in general occurs within the reference system established by the CJEU. Thus, in the canonic Union Royale Belge des Sociétés de Football Association and others $v$ Bosman ${ }^{12}$ case, the CJEU held that the EU possessed an exclusive competence to regulate the exercise of fundamental rights and freedoms in the EU. With these arguments in mind, the CJEU has repeatedly delivered decisions in favour of the EU even in those cases in which the EU had not had an appropriate regulating competence under provisions of EU founding treaties (for example, in the areas of education, ${ }^{13}$ and culture and sports $\left.{ }^{14}\right)$.

Today, regulating competences of the EU are rigidly restricted to issues delegated to it by members through the above-mentioned legal bases. EU acts without a legal basis or which do not follow it to the full extent are regarded as symbolic and contravening the principle of conferral of powers. These acts must be abolished under Article 263 of the TFEU [EU, 2012], which allows the CJEU to supervise the legitimacy of the adoption of EU legislative acts.

In 1992, the CJEU in the France $v$ Commission case held that express indication of the legal bases must be included in any EU legislative act, and the absence of such indication results in the act being declared null and void by the CJEU. ${ }^{15}$ However, this decision has not had an influence on the further law enforcement practice of the CJEU. Not a single EU legislative act challenged by members as being passed without sufficient justification ${ }^{16}$ has been abolished or declared void. At the very best, the CJEU was just reiterating the content of the recital of a legislative act, ${ }^{17}$ relying on the opinion of EU institutions that had elaborated the act in resolving the question of necessity

${ }^{12}$ Case C-415/93, Union Royale Belge des Sociétés de Football Association and others v Bosman. Available at: https://curia.europa.eu/jcms/jcms/j_6/en/ (accessed 12 January 2017).

${ }^{13}$ Case C-9/74, Casagrande v Landeshauptstadt München. Available at: https://curia.europa.eu/jcms/ jcms/j_6/en/ (accessed 12.01.2017).

${ }^{14}$ Case C-415/93, Union Royale Belge des Sociétés de Football Association and others v Bosman. Available at: http:

${ }^{15}$ See, for example: Case C-325/91, France v Commission. Available at: https://curia.europa.eu/jcms/ jcms/j_6/en/ (accessed 12 January 2017).

${ }^{16}$ According to Paul Craig [2012, p. 80], in last 20 years, there were just over 10 cases for abolition or invalidation of EU legislative acts due to an insufficient justification of their adoption.

${ }^{17}$ See, for example: Case C-377/98, Netherlands v. European Parliament and Council; Case C-491/01, British American Tobacco; Joined Case C-154/04 and 155/04 R. v. Secretary of State for Health and National Assembly for Wales; Case C-58/8, Vodafone Ltd, Telefónica O2 Europe plc, T-Mobile International AG, Orange Personal Communications Services Ltd v. Secretary of State for Business, Enterprise and Regulatory Reform. Available at: https://curia.europa.eu/jcms/jcms/j_6/en/ (accessed 12 January 2017). 
of its adoption; ${ }^{18}$ at the worst the CJEU provided a mere statement of the proposing institutions that achievement of the aims of an intended action "necessarily presupposes Community-wide action" ${ }^{19}$ without any accompanying analysis of factual circumstances.

It is definitely impossible in a system based on legal and democratic values to disregard the capability of a court to denote errors of lawmakers in relation to the compliance with rules and procedures determining how lawmakers should exercise their regulating competences. However, any appeal to a more demanding role for the CJEU in policing boundaries of EU legislative competencies [Kumm, 2006, p. 503] poses certain risks of disrupting the institutional balance. In the multilevel constitutional system of the EU, various institutions - participants of the EU lawmaking process having different political views - are involved in determining a level of government for a legislative action. If, making a decision on an EU legislative act that has already been passed by the EU Council and/or European Parliament, the CJEU voices concerns about the improper level of adoption of this act, it inevitably puts itself in a situation in which it must face opposition of a qualified majority of members that believe action at the EU level is required as they supported this action at the lawmaking stage [Craig, 2012, p. 81]. This can create the grounds for accusing the court of "rampant judicial activism" [Toth, 1994, p. 48]. For this reason, the CJEU prefers not to undermine its reputation as an "instrument... of constitutionalization... of communitarian law" [Varlamova, 2014, p. 17]. As a rule it does not engage in political inter-institutional disputes, thus remaining a purely legal institution delivering decisions that are binding for all participants of integration relations.

\section{Legal Integration in the Eurasian Economic Union (EAEU)}

According to T. Risse [2015, p. 1], the institutional design of the EAEU "resembles the EU to a large extent - with one exception: the [EAEU] does not contain provisions to build supra-national institutions, it remains intergovernmental."

Russian researchers correctly indicate that national governments play a major role in the EAEU decision-making process, while EAEU institutions "just provide a platform for their [national governments'] interaction” [Strezhneva, 2016, p. 6]. Even though some institutions have certain supranational features and, therefore according to T. Neshataeva, the EAEU can be regarded as an "organization of the supranational type" [2015], it is still impossible to consider EAEU law as a supranational legal framework in its pure form and within the meaning that has been elaborated and maintained in the EU system.

${ }^{18}$ Case C-176/09, Luxembourg vs Parliament and the Council. Available at: https://curia.europa.eu/jcms/ jcms/j_6/en/ (accessed 12 January 2017).

${ }^{19}$ Case C-84/94, UK $v$ Council. Available at: https://curia.europa.eu/jcms/jcms/j_6/en/ (accessed 12 January 2017). 
Certain supranational features can be traced in the Eurasian Economic Commission (EEC) which is empowered with regulating authority, and in the EAEU Court which is granted authority to ensure the consistent application of international treaties and decisions of EAEU bodies. At the same time, the EAEU Court does not examine appeals by citizens of states related to violations of their rights and freedoms by national legislation passed, for example, in contradiction to decisions of the EEC. This is because decisions of the EEC, despite being subject to direct application in the territories of states, are not given an absolute priority recognized at both Eurasian and national levels over national legislative acts.

Created on the grounds of the Treaty on Eurasian Economic Union, dated 29 May 2014 [EAEU, 2014] EAEU law mostly keeps features of international law as, expanding its regulating potential, it relies on international treaties and EAEU decisions that are not contradictory to these treaties - decisions by EAEU institutions such as the Supreme Eurasian Economic Council, the Eurasian Intergovernmental Council and the EEC (EAEU, 2014, Sect. 6, Clause 1, Para. 5]. In accordance with the decisions of these EAEU bodies, single rules of behaviour for citizens ${ }^{20}$ of states are being created in the EAEU, but these single rules do not form an independent and self-sufficient legal order for its participants, as they are adopted by EAEU bodies within their mandates provided not only by the EAEU Treaty but also by other international treaties ratified by states within the EAEU. Thereby, EAEU institutions originally do not possess founding authority to create a supranational level of legal norms which would have its own scope of regulation independent of other international treaties and an application mechanism not constrained with special national procedures relating to these norms. This is one of the things that prevents EAEU acts from asserting an absolute application priority over acts of EAEU members.

\section{Instruments of Legal Integration in the EAEU}

In addition to international treaties, instruments of legal integration in the EAEU are acts adopted by EAEU bodies and containing regulatory norms. As long as international treaties do not directly serve goals of supranational legal integration, the focus can be on the second element existing in the EAEU legal arena - acts of EAEU bodies. These acts possess features that make legal integration in the EAEU very "intergovernmentally specific."

First, EAEU acts are adopted by EAEU bodies within mandates provided by international treaties ratified by national governments within the EAEU [EAEU, 2014, Sect. 6, Clause 1]. Second, there is a rigid hierarchy of EAEU acts that suggests that decisions of the EEC are subordinate to decisions of the Supreme Council and Intergovernmental Council [Sect. 6, Clause 4]. Third, acts of the Supreme Council and Intergovernmental Council are directed to EAEU members and are supposed to be

\footnotetext{
${ }^{20}$ Here, actors in question are economic units, i.e. entities registered in a manner prescribed by national legislation, including legal entities and self-employed entrepreneurs.
} 
applied in a way determined by their national legislation. At the same time, the Treaty does not explicitly state the binding nature of acts of the Supreme Council and Intergovernmental Council on the institutions of states.

The EEC stands out in this context, as its acts, being subordinate to the legal system of the EAEU (in relation to acts of the Supreme Council and Intergovernmental Council), are still directed to citizens (economic units) of states and are generally applicable in the territories of states according to Clause 13 of the Regulation on the Eurasian Economic Commission that is annexed to the Treaty. These valuable features ensure the supranational nature of acts, but unfortunately the significance of these features for Eurasian legal integration is devalued because the priority of acts of the EEC over acts of national law is not recognized at the EAEU level. Members do not share a single approach to this issue.

For example, the constitution of the Russian Federation does not state the supremacy of legally binding decisions of international organizations and their institutions over domestic legislation. The constitution of the Republic of Belarus directly provides that acts of intergovernmental associations must be subordinate to the national legal system. They may be elevated to a higher level only if international treaties are made on their basis, with such treaties being not ultimately paramount but right below the constitution and constitutional acts [Vasilevich, 2009, p. 15].

The Republic of Kazakhstan has developed a unique approach. According to Clause 3 of Article 4 of Kazakhstan's constitution, ratified international treaties have priority over laws and are applied directly, except in situations when an international treaty requires adoption of a law of the Republic of Kazakhstan. To develop further this constitutional provision, on 5 November 2009 the Constitutional Council of the Republic of Kazakhstan passed a special resolution ${ }^{21}$ establishing that acts of international organizations created pursuant to ratified international treaties and acts of their bodies are included within the national legal system through above-mentioned international treaties. If an international treaty ratified by the Republic of Kazakhstan states that acts of bodies of international organizations are of a binding nature for members, public authorities of the Republic of Kazakhstan must adjust national legislation according to such acts. As a result, if a decision of the EEC contradicts a legislative act of the Republic of Kazakhstan, a decision of the EEC will have priority in the application scheme, and public authorities of the Republic of Kazakhstan will have to amend national legislation accordingly. Unfortunately, this approach to determining the role of acts of EAEU bodies in national legislation is not common to all EAEU members.

For supranational legal integration, it is critical not only to have a single state-level legal approach to determining a role of supranational acts in national legal systems of members of an integration association [Kashirkina, Morozov, 2012, p. 251], but also to ensure that founding acts of the association deal with this issue. S. V. Bakhin [2007,

${ }^{21}$ For the official interpretation of provisions of section 4 of the Constitution of the Republic of Kazakhstan in relation to implementation of decisions of international organizations and their institutions, please see: Resolution of the Constitutional Council of the Republic of Kazakhstan [2009]. 
p. 126] is right when he writes that for the countries in the modern globalizing and integrating world, it is very important to construct a hierarchy that ranks national law and law of international treaties at the national law level, as well as "national law and law of an integration association" consisting of given members, but at the level of law of the integration association.

\section{Judicial Review of Application of Legislation in the EAEU}

As EAEU judge T. Neshataeva [2015] points out, supranational courts are created to ensure the unified interpretation and application of general legal rules, which they do by creating legal norms which "fasten all three types of legal regulation of integration relations: an international treaty, a norm passed by international bureaucracy and a norm passed by national bodies, including national courts." In relation to activities of the CJEU, this claim is correct; in relation to the EAEU Court, it is not: the EAEU Court is not empowered to solve such tasks. This should be examined in more detail.

As follows from Clause 2 of the Statute of the EAEU Court, annexed to the Treaty, the Court ensures the unified application of EAEU law resolving disputes regarding the issues of implementation of this law (Clause 39, Subclauses 1 and 2 of the Statute). However, the EAEU Court is not provided with the competence to endow EAEU bodies with new functions in addition to those directly established by the Treaty and/or other international treaties ratified within the integration association (Clause 42 of the Statute).

Decisions of the EAEU Court "do not modify and do not override existing norms of EAEU law, national legislation and do not create new norms" (Clause 102 of the Statute), and prejudicial rulings of the EAEU Court do not have a binding nature for national jurisdictional bodies that are requested to deliver such rulings (Clause 98 of the Statute). Taking into consideration the critical importance of prejudicial rulings for setting up a lawmaking and law-enforcement dialogue between supranational and national judicial bodies, the wording of Clause 98 of the Statute confirms, as A. S. Ispolinov argues, "the disregard of legislative acts of the integration association by member states, primarily by their national courts" [2017, p. 115]. This is the first competence-related impediment created by the authors of the Treaty that makes it impossible to secure the unified interpretation and application of norms of EAEU law.

The second impediment is linked to the necessity of compliance with the procedure of pre-court mediation for disputes on the legitimacy of decisions of the EEC in terms of their conformity to international treaties and decisions of EAEU institutions. This procedure is applied in relation to disputes initiated not only by member states but also by economic units. The EAEU Court takes up a dispute only if an applicant previously submitted a claim to the EEC (Clause 43 of the Statute). At the same time, the Statute does not introduce a procedure of judicial appeal against the results of precourt mediation, which, for example, may be unsatisfactory for an economic unit if it still believes that its rights and legitimate interests granted by the Treaty have been 
violated by a decision of the EEC. Only if the EEC fails to take action may a dispute be taken up by the EAEU Court (Subclause 44 of the Statute). The rule demanding that applicants use the procedure of pre-court mediation works as a bottleneck" for individuals and legal entities doing business in the EAEU as it significantly narrows their opportunities to be upheld by the court at the Eurasian level. While states can use alternative methods to protect their interests and prerogative powers (for example, by appealing to the Supreme Council), economic units are unable to do so. ${ }^{22}$ Unfortunately, this circumstance was either not addressed by the authors of Eurasian integration or, conversely, this tactic was intentionally used to "constrain activities and the broadening of authority of the [supranational] court” [Ispolinov, 2017, p. 116].

\section{The Formal Parliamentary Element in the EAEU}

Another formal impediment of communitarian integration in the EAEU mentioned in the literature is that the EAEU lacks "the formal parliamentary element" [Likhachev, 2014] which would interact with other EAEU institutions in the process of making Eurasian decisions. However, the issue of supranational parliamentarism is not as clear as the issue of supranational courts and the experience of the EU proves it.

The presence of a supranational parliament itself does not ensure the supranational nature of legal integration. The role of the European Parliament in legal integration in the EU is controversial. "European Parliament does not share many of the democratic credentials of national parliaments, remains distant from citizens and within the process of EU decision-making may be viewed as part of the legitimacy problem [in the EU]." [EU Select Committee, 2013, p. 40]. Today, Europe looks at national parliaments as a means to protect democratic legitimacy to an extent that cannot be achieved by EU institutions themselves in the process of supranational legal integration. The European Parliament is physically unable to replace national parliaments in regard to certain issues of legislative policy which fall within regulating competences of EU members but which require the adoption of harmonization measures by the EU: national parliaments, being local, remain politically responsible for the situation in their states, and this positions them as unique bodies for elaborating EU legislative acts. Guided by these motives, the Lisbon Treaty developed as a founding element a special tool (the so-called subsidiarity control mechanism) which allows national parliaments to take part in the EU law-making process, not substituting the European Parliament, the EU Council or the EU Commission, but directly cooperating with them, as well as with each other, on the question of what level of government is proper regulating authority.

Perhaps, the EAEU should also turn to the national parliaments of its members as unique actors in the process of rendering Eurasian decisions. National parliaments, by participating, for example, in the exercise of regulating competences of the EEC could

${ }^{22}$ In the EU, the procedure of pre-court mediation is not used for disputes between individuals and EU bodies that have passed an act under question. Pre-court mediation is only applied to disputes between EU member states. That said, it is still possible to appeal to the CJEU if a decision of the EU Commission is absent (See Art. 259 of the TFEU [EU, 2012]). 
enhance the democratic legitimacy of its acts (through the same subsidiarity control mechanism evaluating the justification for delegation of certain functions and implementation of these functions at the level of the EEC), and contribute to a better local implementation. Being politically responsible to their voters, national parliaments can serve links between the EAEU and the citizens of its members, enabling citizens to take part (through their parliamentary representatives) at the Eurasian level in the development and adoption of legislative acts regulating integration relations involving not just their states, but themselves. The attainment of parliamentary legitimacy of acts of EAEU bodies could definitely be an important step toward supranational legal integration, which is the aim that the EAEU wants to achieve. However, in order to turn an apprentice into a master, it is required not only to have an intention and spend time; it is necessary to have a better developed mechanism, from the institutional point of view, for the adoption of supranational decisions which would involve all participants of integration relations equally in the joint process of solving problems, rather than have them persistently advancing their own interests.

\section{Conclusion}

Of course, legal integration in the EU is completely different from legal integration within the EAEU from both the formal legal standpoint, as these associations follow different integration evolution pathways, and the practical standpoint, as they achieve different results. The EU and the EAEU have developed totally opposite mechanisms for adopting integration decisions, which have different natures.

Legislative acts passed in the EAEU are not given an absolute priority over acts of national legislation of its members, which results in a lack of consistency and unity on this issue among members - this was the key reason for focusing substantive research efforts on legislation of individual members of the EAEU while leaving aside relevant legislation of EU members). The EU faces precisely the reverse situation: its acts at the founding level (starting with the Single European Act) have created preconditions for endowing EU institutions with founding competences to compose an independent supranational layer of legal acts that are superior and directly applied in the territories of states. States are cooperative and unified in how they follow the decisions of the CJEU and secure the proper implementation of acts of the EU Commission.

The utilization of capacity and tools of states for attaining integration development aims is the strategically beneficial approach to integration development. Good will and the consent of members of an integration association can help attain all ambitious aims in relation to integration. For this reason, the mechanism of adoption of decisions itself becomes a key element for the success of the subsequent implementation of these decisions. And fortunately, the chosen method of integration development, even though it sets the appropriate tone for implementation processes, does not predetermine their outcome. 
The communitarian method appeals to the legislative procedure of inter-institutional interaction involving national parliaments, while the conventional method appeals to intergovernmental negotiations. However, in both cases, decision-making actors endeavour to achieve the same outcome - to completely eliminate the possibility that supranational decisions may be inconvenient for national implementing authorities [Glencross, 2014, p. 70]. This can be brought into action through the reconciliation of wills of decision-making actors on the basis of their dialogue. The most effective collective decisions are taken on the basis of consensus and not on the basis of priority of the will of majority. Here, a consensus is supposed to be reached via the inter-institutional dialogue (inter-institutional consensus) of decision-making actors localized at various levels of integration management. It is crucial to directly involve those who will be responsible for implementation of these decisions locally. The EU law-making process is characterized by the multipolarity and complexity of reconciliation of positions of its participants and provides for institutional engagement of citizens of states though their parliaments. These parliaments directly interact in the framework of the subsidiarity control mechanism with supranational institutions exercising regulating competencies of the EU, which is recognized as a basic guarantee that positions of all interested and affected stakeholders will be taken into consideration in supranational legislative decisions to the fullest extent. And even though a qualified majority in the Council and/or a majority in the European Parliament is required for passing legislative decisions, this aspect of the legislative process nonetheless does not offset the purely inter-institutional nature of this process.

In its turn, it is important to note that decisions of the Council of the EEC (as a body exercising oversight functions over EEC activities), also require a consensus. If one is not reached an issue under question is passed for consideration to the Supreme Council (Clause 29 of the Regulation on the Eurasian Economic Commission annexed to the Treaty). However, the situation with the Eurasian consensus is of quite a different type: given that the Council of the EEC consists of five vice-premiers representing national governments of EAEU members, it would be unreasonable to claim that this body, as well as the decision-making procedure that it has developed, is inter-institutional by their nature.

The genuinely consensual nature of supranational decisions provides an avenue for their procedural legitimacy and, therefore, for the uncomplicated implementation by all participants of integration relations involved in adoption of these decisions as well as in their direct application by citizens. It appears to be the main lesson learned from integration development in the EU, where inter-institutional consensus has become a gold standard for the legal approximation of states. 


\section{References}

Bakhin S.V. (2007) Mezhdunarodnaya sostavliaiushchaya pravovoi sistemy Rossii [The International Component of Russia's Legal System]. Pravovedenie [Jurisprudence], no 6, pp. 126-137. (In Russian)

Chirkin V.E. (2016) Nadnatsional'noe pravo: vozniknovenie, soderzhanie, deistvie [Supranational Law: Emergence, Content, Action]. Aktual'nye problemy rossiiskogo prava [Current Problems of Russian Law], no 1, pp. 18-25. (In Russian)

Cooper I. (2017) Is the Early Warning Mechanism a Legal or a Political Procedure? Three Questions and a Typology. National and Regional Parliaments in the EU-Legislative Procedure Post-Lisbon (A. Cornell A., M. Goldoni (eds)). London: Hart, pp. 36-43.

Constitutional Council of the Republic of Kazakhstan (2009) Resolution No. 6. Available at: http://online.zakon.kz/document/?doc_id=30519643\#pos=0;0 (accessed 29 January 2019).

Craig P. (2012) Subsidiarity: A Political and Legal Analysis. Journal Common Market Studies, vol. 50, pp. $80-83$.

Ellinek G. (2004) Obshchee uchenie o gosudarstve [General Doctrine of the State]. St. Petersburg: Litigant Legal Centre. (In Russian)

Entin L.M. (2009) Pravo Evropeiskogo Soiuza. Novyi etap evoliutsii: 2009-2017 [European Union Law: New Stage of Evolution: 2009-2017]. Moscow: Aksiom. (In Russian)

Eurasian Economic Union (EAEU) (2014) Treaty on the Eurasian Economic Union. Available at: https://docs.eaeunion.org/ru-ru/Pages/DisplayDocument.aspx?s=bef9c798-3978-42f3$9 \mathrm{ef} 2-\mathrm{d} 0 \mathrm{fb} 3 \mathrm{~d} 53 \mathrm{~b} 75 \mathrm{f} \& \mathrm{w}=632 \mathrm{c} 7868-4 \mathrm{ee} 2-4 \mathrm{~b} 21-\mathrm{bc} 64-1995328 \mathrm{e} 6 \mathrm{ef} 3 \& \mathrm{l}=540294 \mathrm{ae}-\mathrm{c} 3 \mathrm{c} 9-4511-9 \mathrm{bf} 8$ aaf5d6e0d169\&EntityID=3610 (accessed 29 January 2019).

European Union (EU) Commission (2001) European Governance: A White Paper. COM (2001) 428 Final, 25 July.

European Union (EU) (2012) Treaty on the Functioning of the European Union. Available at: https:// eur-lex.europa.eu/legal-content/EN/TXT/PDF/?uri=CELEX\%3A12012E/TXT (accessed 29 January 2019).

European Union (EU) Select Committee (2013) The Role of National Parliaments in the European Union: Written Evidence. Available at: https://www.parliament.uk/documents/lords-committees/euselect/Role\%20of\%20national\%20parliaments/national-parliaments-evidence.pdf (accessed 19 January 2019).

Glencross A. (2014) The Politics of European Integration: Political Union or a House Divided? Oxford: Wiley.

Ispolinov A.S. (2017) Chto skryvaetsia za broskim terminom "integratsionnoe pravosudie" [What is Behind the Catchy Term "Integrative Justice"]? Pravo: Zhurnal Vysshei shkoly ekonomiki [Right: Journal of the Higher School of Economics] no 3, pp. 105-120. (In Russian)

Iumashev Iu.M. (2006) Regional'naia integratsiia i mezhdunarodnye otnosheniia [Regional Integration and International Relations]. Moskovskii zhurnal mezhdunarodnogo prava [Moscow Journal of International Law], no 1, pp. 75-87. (In Russian)

Kashirkina A.A., Morozov A.N. (2012) Mezhdunarodno-pravovye modeli Evropeiskogo Soiuza i Tamozhennogo soiuza: sravnitel'nyi analiz [International Legal Models of the European Union and the Customs Union: A Comparative Analysis]. Moscow: Institute of Legislation and Comparative Law Under the Government of the Russian Federation. (In Russian)

Khol'tsinger G. (2014) Konstitutsionnoe gosudarstvo v Evropeiskom soiuze [Constitutional State in the European Union]. Sovremennyi konstitutsionalizm: vyzovy i perspektivy [Modern Consitutionalism: Challenges and Prospects] (V.D. Zor'kin (ed.)). Moscow: NORM. (In Russian)

Kumm M. (2006) Constitutionalising Subsidiarity in Integrated Markets: The Case of Tobacco Regulation in the European Union. European Law Review, vol. 12, no 4. 
Lenaerts K., Nuffel P. (2011) European Union Law. London: Sweet \& Maxwell.

Lenaerts K. (1993) The Principle of Subsidiarity and the Environment in the European Union: Keeping the Balance of Federalism. Fordham International Law Journal, vol. 17, no 4.

Likhachev V. (2014) Integratsiia i zakon: EAES nuzhna normativnaia komponenta [Integration and Law: The EAEU Needs a Regulatory Component]. Rossiiskaia gazeta [Russian Gazette], 24 December. (In Russian)

Magnette P. (2000) L'Europe, L'État et la Démocratie: Le Souverain Apprivoisé. Brussels: Complexe.

Majone G. (2009) Europe As the Would-be World Power: Europe at Fifty. Cambridge: Cambridge University Press.

Meshcheriakova O.M. (2014) Lissabonskii Dogovor i problema rasshireniia funktsii institutov ES [The Treaty of Lisbon and the Problem of Expanding the Functions of EU Institutions]. Vestnik Volgogradskogo gosudarstvennogo universiteta. Ser. 5, Iurisprudentsiia [Bulletin of Volgograd State University: Series 5, Jurisprudence], no 3 (24), pp. 139-142. (In Russian)

Middelaar L. (2013) The Passage to Europe, How a Continent Became a Union. New Haven and London: Yale University Press.

Moorhead T. (2012) European Union Law as International Law. European Journal of Legal Studies, vol. 5, no 1, pp. 126-143.

Neshataeva T.N. (2015) Integratsiia i nadnatsionalizm [Integration and Supranationalism]. Otrasli prava: analiticheskii portal [Branch Rights: Analytical Portal]. Available at: http://отрасли-права.pф/article/2679 (accessed 02 February 2019).

Puetter U. (2014) Governing Informally: The Role of the Eurogroup in EMU and the Stability and Growth Pact. Journal of European Public Policy, vol. 11, no 5, pp. 854-870.

Risse T. (2015) The Diffusion of Regionalism, Regional Institutions, Regional Governance. Paper presented at the EUSA 2015 Conference, Boston. Available at: https://www.eustudies.org/conference/papers $/ 11$ ? token $=\mathrm{pDqnRLkX0Eaw8gqXHDDYJiHY5AQR2IJYDJQ1WD2G \& criteria=author \& keywor}$ $\mathrm{ds}=$ risse \&submit $=($ accessed 19 February 2016) .

Strezhneva M. (2016) Nadnatsional'nost' i printsip subsidiarnosti v ES i za ego predelami [Nationality and the Principle of Subsidiarity in the EC and in Ego Predecessors. Mirovaia ekonomika i mezhdunarodnye otnosheniia [World Economy and International Relations], vol. 60, no 6, pp. 5-12. (In Russian)

Toth A. (1994) A Legal Analysis of Subsidiarity. Legal Issues of the Maastricht Treaty (D. O'Keeffe, P. Twomey (eds)). London: Chancery.

Uçarer E.M. (2013) Area of Freedom, Security, and Justice. European Union Politics (M. Cini, N. PerezSolorzano Barragán (eds)). Oxford: Oxford University Press, pp. 281-295.

Varlamova N.V. (2014) Problemy institutsionalizatsii nadnatsional'nogo urovnia osushchestvleniya publichno-vlastnykh polnomochii [Problems of Institutionalization of the Supranational Level of Public Authority]. Internatsionalizatsiia konstitutsionnogo prava $v$ usloviiakh globalizatsii [Internationalization of Constitutional Rights in the Context of Globalization] (T.A. Vasiliev (ed.)). Moscow: Institute of State and Rights, Russian Academy of Sciences. (In Russian)

Vasilevich G.A. (2009) Mezhdunarodnoe pravo i natsional'noe zakonodatel'stvo [International Law and National Legislation]. Moscow: Eksmo. (In Russian)

Waele H., Vleuten A. (2013) Judicial Activism in the European Court of Justice: The Case of LGBT Rights. Michigan State International Law Review, vol. 19, pp. 644-665. 


\title{
Правовая интеграция в Европейском союзе и Евразийском экономическом союзе: сравнительный анализ ${ }^{1}$
}

\author{
О.И. Пименова
}

Пименова Оксана Игорьевна - к.ю.н., начальник отдела по взаимодействию с федеральными органами государственной власти Аппарата Совета Федерации Федерального Собрания Российской Федерации; 103426, Российская Федерация, г. Москва, ул. Большая Дмитровка, д. 26; E-mail: oxana_krasnova@mail.ru

В статье рассматриваются коммунитарная и конвенционная модели правовой интеграции, принятые в Европейском союзе и Евразийском экономическом союзе соответственно. Анализ проводится в сравнительно-правовом разрезе с целью выявить те уникальные черты, использование которых способствует решению актуальных задач интеграционного развития. Особое внимание уделяется исследованию актов органов Европейского союза и Евразийского экономического союза, их правовой природы, места, роли и специфики имплементации в национальных правопорядках государств-членов. Автор анализирует также деятельность Суда Европейского союза и Суда евразийского экономического союза по контролю реализации права Европейского союза и права Евразийского экономического союза в части правомерности принятия наднациональными органами данных интеграционных объединений правовых актов, создающих права и обязанности непосредственно для граждан Европейского союза и хозяйствующих субъектов в Евразийском экономическом союзе. В статье обосновывается идея о том, что безусловный приоритет интеграционного права над национальным законодательством и юридическая обязательность решений наднационального судебного органа для всех участников интеграционных отношений выступают теми «вехами» наднациональной правовой интеграции, при достижении которых становится возможным открытие государственных грании не только в сферах экономического сотрудничества, но и в других областях взаимодействия, прямо не связанных с общими процессами транснационализации экономик.

Ключевые слова: Европейский союз; Евразийский экономический союз; наднациональность; правовая интеграция; законодательный акт; судебный контроль; национальные парламенты; демократическая легитимность; межинституциональный консенсус

Для цитирования: Пименова О.И. (2019) Правовая интеграция в Европейском союзе и Евразийском экономическом союзе: сравнительный анализ // Вестник международных организаций. Т. 14. № 1. C. 76-93. DOI: 10.17323/1996-7845-2019-01-05

\section{Источники}

Бахин С.В. (2007) Международная составляющая правовой системы России // Правоведение. № 6. C. $126-137$.

Варламова Н.В. (2014) Проблемы институционализации наднационального уровня осуществления публично-властных полномочий // Интернационализация конституционного права в условиях глобализации: труды Института государства и права Российской академии наук № 6 / Т.А. Васильева (ред.). М.: Институт государства и права Российской академии наук. С. 13.

Василевич Г.А. (2009) Международное право и национальное законодательство. М.: Эксмо. С. 151. Еллинек Г. (2004) Общее учение о государстве. СПб.: Литагент «Юридический центр». С. 413-416. Исполинов А.С. (2017) Что скрывается за броским термином «интеграционное правосудие»? // Право. Журнал Высшей школы экономики. № 3. С. 105-120.

Каширкина А.А., Морозов А.Н. (2012) Международно-правовые модели Европейского союза и Таможенного союза: сравнительный анализ. М.: Институт законодательства и сравнительного правоведения при Правительстве Российской Федерации; Контракт. С. 17.

\footnotetext{
${ }^{1}$ Статья поступила в редакцию в апреле 2018 г.
} 
Конституционный Совет Республики Казахстан (2009) Постановление № 6. Режим доступа: http:// online.zakon.kz/document/?doc_id=30519643\#pos=0;0 (дата обращения: 02.02.2017).

Лихачев В. (2014) Интеграция и закон: ЕАЭС нужна нормативная компонента // Российская газета. 24 декабря.

Мещерякова О.М. (2014) Лиссабонский Договор и проблема расширения функций институтов ЕС // Вестник Волгоградского государственного университета. Серия 5. Юриспруденция. № 3 (24). C. $139-142$.

Нешатаева Т.Н. (2015) Интеграция и наднационализм. Отрасли права: аналитический портал. Режим доступа: http://отрасли-права.рф/article/2679 (дата обращения: 18.02.2018).

Стрежнева М. (216) Наднациональность и принцип субсидиарности в ЕС и за его пределами // Мировая экономика и международные отношения. Т. 60. № 6. С. 5-12.

Хольцингер Г. (2014) Конституционное государство в Европейском союзе // Современный конституционализм: вызовы и перспективы / В.Д. Зорькин (ред). М.: Норма. С. 40-41.

Чиркин В.Е. (2016) Наднациональное право: возникновение, содержание, действие // Актуальные проблемы российского права. № 1. С. 18-25.

Энтин Л.М. (2009) Право Европейского Союза. Новый этап эволюции: 2009-2017 годы. М.: Аксиом. C. 238.

Юмашев Ю.М. (2006) Региональная интеграция и международные отношения // Московский журнал международного права. № 1. С. 75-87.

Cooper I. (2017) Is the Early Warning Mechanism a Legal or a Political Procedure? Three Questions and a Typology // National and Regional Parliaments in the EU-Legislative Procedure Post-Lisbon / A. Cornell, M. Goldoni (eds)). L.: Hart. P. 36-43.

Craig P. (2012) Subsidiarity: A Political and Legal Analysis // Journal Common Market Studies. Vol. 50. P. 80-83. European Union (EU) Commission (2001) European Governance: A White Paper. COM (2001) 428 Final. 25 July. European Union (EU) Select Committee (2013) The Role of National Parliaments in the European Union: Written Evidence. Режим доступа: http://www.publications.parliament.uk/pa/ld201314/ldselect/ldeucom/151/151.pdf/ (дата обращения: 19.02.2016).

Glencross A. (2014) The Politics of European Integration: Political Union or a House Divided? Oxford: Wiley. P. 70

Kumm M. (2006) Constitutionalising Subsidiarity in Integrated Markets: The Case of Tobacco Regulation in the European Union // European Law Review. Vol. 12. No. 4. P. 503.

Lenaerts K., Nuffel P. (2011) European Union Law. L.: Sweet \& Maxwell. P. 134.

Lenaerts K. (1993) The Principle of Subsidiarity and the Environment in the European Union. Keeping the Balance of Federalism // Fordham International Law Journal. Vol. 17. No. 4. P. 884.

Magnette P. (2000) L'Europe, L'État et la Démocratie: Le Souverain Apprivoisé. Brussels: Complexe. P. 117.

Majone G. (2009) Europe As the Would-be World Power: Europe at Fifty. Cambridge: Cambridge University Press. P. 2.

Moorhead T. (2012) European Union Law as International Law // European Journal of Legal Studies. Vol. 5. No. 1. P. 126-143.

Puetter U. (2014) Governing Informally: The Role of the Eurogroup in EMU and the Stability and Growth Pact // Journal of European Public Policy. Vol. 11. No. 5. P. 854-870.

Risse Th. (2015) The Diffusion of Regionalism, Regional Institutions, Regional Governance. Paper presented at the EUSA 2015 Conference, Boston, USA. Режим доступа: https://www.eustudies.org/conference/papers/11?_token=pDqnRLkX0Eaw8gqXHDDYJiHY5AQR2IJYDJQ1WD2G\&criteria=author\&keywords=ris se\&submit= (дата обращения: 19.02.2016).

Toth A. (1994) A Legal Analysis of Subsidiarity // Legal Issues of the Maastricht Treaty / D. O'Keeffe, P. Twomey (eds). L.: Chancery. P. 48.

Uçarer E.M. (2013) Area of Freedom, Security, and Justice // European Union Politics / M. Cini, N. PerezSolorzano Barragán (eds). Oxford: Oxford University Press. P. 281-295.

Waele H., Vleuten A. (2013) Judicial Activism in the European Court of Justice - The Case of LGBT Rights // Michigan State International Law Review. Vol. 19. P. 644-665. 